DEVELOPMENT OF MANAGEMENT

AND ENTREPRENEURSHIP METHODS

ON TRANSPORT, № 3 (76), 2021
РОЗВИТОК МЕТОДІВ

УПРАВЛІННЯ ТА ГОСПОДАРЮВАННЯ

НА ТРАНСПОРТІ, № 3 (76), 2021

\section{УдК 656.615 \\ JEL A10:D10 \\ DOI 10.31375/2226-1915-2021-3-5-16 \\ МЕТОДИКА ОЦІНКИ РІВНЯ ЕФЕКТИВНОСТІ ВИКОРИСТАННЯ ВИРОБНИЧОГО ПОТЕНЦАЛУ ПІДПРИЕМСТВА ПОРТОВОЇ ДІЯЛЬНОСТІ}

\section{Л.П. Чиж}

к. е. н., проф. кафедри «Економіка та фінанси» Н.В. Хотсева

к. е. н., доцент кафедри «Економіка та фінанси» К.О. Загородня

магістрант кафедри «Економіка та фінанси»

Одеський національний морський університет, м. Oдеса

Анотація. Обмеженість можливостей розвитку практично для кожного підприємства потребує наявності відповідної методики оцінки використання виробничого потенціалу підприсмства. Вивчаючи проблеми визначення ефективності виробничого потенціалу, слід обов'язково розглянути підходи до його оцінки. Комплексна оцінка виробничого потенціалу підприсмства - необхідний етап стратегічного і антикризового аналізу та управління. Велика кількість підходів оцінювання виробничого потениіалу підприємства не завжди відповідає економічним умовам, не всі підходи доитільно використовувати для оцінки виробничого потенціалу портового підприсмства. Оиінка кожної складової виробничого потенціалу надає змогу не тільки визначити загальний рівень потенціалу, а також оцінити ефективність використання ресурсів у залежності від значення окремих показників. Іниі підходи скоріме визначають загальний рівень потенціалу, не фокусуючи увагу на оцінки повноти його використання.

Ключові слова: потенциіал підприємства, виробничий потенціал, методика оцінки, виробничі можливості, оцінка ефективності, управління підприємством.

\section{(С) Чиж Л.П., Хотєєва Н.В., Загородня К.О., 2021}

\author{
УДК 656.615 \\ JEL A10:D10 \\ DOI 10.31375/2226-1915-2021-3-5-16
}

\author{
МЕТОДИКА ОЦЕНКИ УРОВНЯ \\ ЭФФЕКТИВНОСТИ ИСПОЛЬЗОВАНИЯ \\ ПРОИЗВОДСТВЕННОГО ПОТЕНЦИАЛА \\ ПРЕДПРИЯТИЯ ПОРТОВОЙ ДЕЯТЕЛЬНОСТИ \\ Л.П. Чиж \\ к. е. н., проф. кафедры \\ «Экономика и финансы» \\ Н.В. Хотеева \\ к. е. н., доцент кафедры \\ «Экономика и финансы» \\ К.О. Загородная \\ магистрант кафедры «Экономика и финансы» \\ Одесский нацииональный морской университет,$$
\text { 2. Oдесса }
$$

Аннотация. Ограниченность возможностей для развития, практически для каждого предприятия, требует наличия соответствующей методики оценки использования производственного потенцииала предприятия. Изучая проблемы определения эффективности производственного потенциала, следует обязательно рассмотреть подходы к его оченке. Комплексная оценка производственного потенциала предприятия - необходимый этап стратегического и антикризисного анализа и управления. Большое количество подходов оценивания производственного потенцииала предприятия не всегда соответствует экономическим условиям, не все подходы иелесообразно использовать для оченки производственного потенциала портового предприятия. Оценка каждой составляющей производственного потенциала дает возможность не только определить общий уровень потенциала, а также оченить эффективность использования ресурсов 6 зависимости от значения отдельных показателей. Другие подходы скорее определяют общчий уровень потенцичала, не фокусируя внимание на оценки полноть его использования.

Ключевые слова: потенциал предприятия, производственный потенцииал, методика оценки, производственные возможности, оценка эффективности, управление предприятием. 
UDC 656.615

JEL A10:D10

DOI 10.31375/2226-1915-2021-3-5-16

\title{
METHODS OF EVALUATION OF EFFICIENCY OF USE OF PRODUCTION POTENTIAL OF PORT ENTERPRISE
}

\author{
Lyudmila Chiz \\ Ph.D., prof. Department «Economics and Finance» \\ ORCID: https://orcid.org/0000-0002-8067-2346 \\ Natalia Khoteeva \\ Ph.D., Associate Professor Department «Economics and Finance» \\ ORCID: https://orcid.org/0000-0002-3858-6540 \\ Karina Zagorodnya \\ Master's student of the Department «Economics and Finance» \\ Odessa National Maritime University, Odessa, Uktaine
}

\begin{abstract}
Limited development opportunities for almost every company requires an appropriate methodology for assessing the use of production potential of the enterprise. The organization of the production capacity assessment procedure should be considered as a system. On the one hand, it must be comprehensive to ensure the completeness of the information field for all types of resources and the purpose of their use, on the other hand, in order to save costs, it is advisable to combine this system with the control system of the enterprise. When studying the problems of determining the effectiveness of resource potential, it is necessary to consider approaches to its evaluation. Comprehensive assessment of the production potential of the enterprise is a necessary stage of strategic and crisis analysis and management. A large number of approaches to assessing the production potential of the enterprise does not always correspond to economic conditions, not all should be used to assess the production potential of the port enterprise. Assessment of each component of production capacity allows not only to determine the overall level of capacity, but also to assess the efficiency of resource use depending on the value of individual indicators. Other approaches are more likely to determine the overall level of capacity, without focusing on assessing the completeness of its use.

The clarification of criteria for assessing production potential is required. The change in indicators that can be useful for assessing the level of potential depends on the specialization. For example, for the port industry, indicators include the use of fixed assets. To establish specific assessment criteria, it is necessary to group port enterprises according to the overall level of capacity.

Assessment of production potential of enterprise is an important stage of management, which is the basis for determining the level of capacity and optimization of management decisions on its development.
\end{abstract}

Keywords: enterprise potential, production potential, evaluation methods, production capabilities, efficiency evaluation, enterprise management. 
DEVELOPMENT OF MANAGEMENT

AND ENTREPRENEURSHIP METHODS ON TRANSPORT, № 3 (76), 2021
РОЗВИТОК МЕТОДІВ

УПРАВЛІННЯ ТА ГОСПОДАРЮВАННЯ

НА ТРАНСПОРТІ, № 3 (76), 2021
Постановка проблеми. На сучасному етапі обмежених можливостей розвитку практично для кожного підприємства дуже актуальною $є$ проблема наявності відповідної методики оцінки використання виробничих ресурсів, іншою мовою виробничого потенціалу підприємства.

Від ступеня ii вдосконалення залежить кінцева результативність господарської діяльності. На сьогоднішній день актуальним є розвиток виробничого потенціалу підприємства, ефективне використання якого сприяє підтриманню належного рівня конкурентоспроможності. Дослідження виробничого потенціалу можна проводити в різних аспектах, що урізноманітнюе методичні підходи до його виміру та результатів його використання. Звідси пошук оптимального методу оцінки ефективності виробничого потенціалу як елемента управлінської діяльності на підприємстві має значне практичне значення.

Огляд останніх досліджень і публікацій. Питання визначення сутності виробничого потенціалу і його ефективного використання $\epsilon$ предметом дослідження провідних вченихекономістів. Особливу увагу цьому питанню у своїх працях приділяють такі науковці: Бай C.I. [1], Воронкова А.Е. [2], Краснокутська Н.С. [3], Лапін Є.В. [4], Отенко І.П. [5], Трофименко А.Н. [8], Федонін О.С. [9], Якушева Е.С. [10] та інші. Проте єдиної комплексної та оптимальної методики оцінки ефективності виробничого потенціалу не створено і дослідження питань діагностики та пошуку шляхів підвищення ефективності виробничого потенціалу залишаються актуальними.
Завдання дослідження. Мета дослідження - оцінити методичні підходи до оцінки ефективності використання виробничого потенціалу та запропонувати один із методів для оцінки ефективності використання виробничого потенціалу підприємства портової діяльності.

Основний матеріал дослідження. Соціально-економічні процеси ринкових перетворень в Україні характеризуються суттєвими змінами умов господарювання будь-якого підприємства.

Рішення проблеми обмеженості ресурсів підприємства вимагає глибокого дослідження, в зв'язку з чим необхідно регулярно моніторити ефективність використання всіх складових виробничого потенціалу.

Вивчаючи проблеми визначення ефективності ресурсного потенціалу, слід обов'язково розглянути підходи до його оцінки.

Сутнісне наповнення категорії «потенціал», згідно із словниками [3], характеризує силу, можливість, спроможність. Щодо підприємства потенціал повинен характеризувати його сутність. Тому визначення потенціалу підприємства має здійснюватися відповідно до теорій підприємства.

Дослідження потенціалу підприємства необхідно починати з його виробничих функцій, провідну роль яких визначали представники та послідовники неокласичної економічної теорії, радянські вчені [6] та сучасні дослідники. Тому стрижнем потенціалу підприємства доцільно визначити його виробничий потенціал, який $\epsilon$ основним, оскільки забезпечує спроможність для формування і використання інших складових потенціалу 
DEVELOPMENT OF MANAGEMENT

AND ENTREPRENEURSHIP METHODS ON TRANSPORT, № 3 (76), 2021
РОЗВИТОК МЕТОДІВ

УПРАВЛІННЯ ТА ГОСПОДАРЮВАННЯ

НА ТРАНСПОРТІ, № 3 (76), 2021 підприємства - інноваційного, інвестиційного, трудового, інтелектуального та інших.

Виробничий потенціал в першу чергу пов'язують 3 матеріальними ресурсами підприємства.

Для обгрунтування сучасних напрямків фінансування інвестицій в розвиток морських портів України, в рамках даного дослідження та на основі проведеного аналізу було запропоновано виходити 3 оцінки їхнього виробничого потенціалу. Це дозволить нам, з однієї сторони, визначити конкурентні переваги та причини відставання в економічному розвитку кожного морського порту, а $з$ іншої провести порівняльний аналіз наявних виробничих потужностей портової системи України з існуючою та прогнозною ємністю ринку морських перевезень. Поєднання вказаних результатів досліджень дозволить сформувати пріоритетні напрямки фінансування інвестицій в розвиток портової системи.

На відміну від промислового виробництва, морський транспорт має певну специфіку галузевої діяльності: по-перше, кожний морський порт, внаслідок свого географічного розташування та природніх умов, має особистий режим плавання, який містить обмежувальний характер на довжину, ширину та осадку суден. Це, в свою чергу, має безпосередній вплив на вантажопідйомність суден, які можуть обслуговуватись в них. Це не може не впливати на виробничий потенціал вказаних суб'єктів господарювання.

По-друге, для здійснення вантажних робіт використовуються причали, кількість яких та довжина є ін- дивідуальними технічними параметрами окремого порту. Виконання спеціалізованих вантажних робіт відбувається на портових терміналах. Один термінал може обслуговувати декілька причалів, або на одному причалі може функціонувати декілька терміналів. Таким чином, кожний порт в термінах теорії масового обслуговування можна представити певною множиною обслуговуючих пристроїв 3 відповідною пропускною здатністю.

По-третє, ефективна перевалка вантажу неможлива без наявності відповідних умов його зберігання. Тому наявні відкриті та криті складські площі $є$ важливою умовою формування виробничого потенціалу морських портів.

По-четверте, виробничі потужності морського порту залежать від його пропускної спроможності 3 обробки наливних, сухих вантажів та контейнерів.

Найбільший синергетичний ефект 3 точки зору виробничого потенціалу морських портів України буде досягатись у тому випадку, коли найкращі умови для заходу великовантажних суден будуть знаходитись в кореляції з чисельністю та пропускною спроможністю каналів їхнього обслуговування, а також 3 умовами зберігання вантажів.

Тож, саме виробничий потенціал визначає i забезпечує унікальність пропозицій підприємств, створює можливості для розвитку.

Принципово складною задачею $€$ оцінювання потенціалу, адже питання про кількісну визначеність виробничого потенціалу багато в чому є дискусійним. 
Організація процедури оцінки виробничого потенціалу повинна бути розглянута як система. 3 одного боку, вона має бути комплексною, тобто забезпечувати повне збирання та обробку інформації по всіх виділених ресурсів і мета їх використання, 3 іншого боку, з метою економії витрат найкраще поєднувати дану функцію 3 функціями системи контролю.

Комплексна оцінка виробничого потенціалу підприємства - необ- хідний етап стратегічного і антикризового аналізу та управління.

Розроблені схеми алгоритму та встановлене місце цього алгоритму універсальні схеми, які підприємство має можливість застосовувати при стратегічному аналізі діяльності.

Основні методи визначення виробничого потенціалу, які систематизовані за методикою розрахунку, згруповані у табл. 1.

Таблиия 1

Методичні підходи до оцінки виробничого потенціалу

та доцільність використання цьього методу для оцінки виробничого потенціалу портового підприємства

\begin{tabular}{|c|c|c|c|c|}
\hline Назва методу & Зміст методу & Переваги & Недоліки & Доцільність \\
\hline Витратний & $\begin{array}{l}\text { Встановлюється на } \\
\text { рівні суми витрат на } \\
\text { активну частину } \\
\text { основних засобів, тех- } \\
\text { нологічний персонал, } \\
\text { частину оборотних } \\
\text { активів, технологію } \\
\text { та інформацію }\end{array}$ & $\begin{array}{l}\text { Точне } \\
\text { вирахування } \\
\text { кіль-кості } \\
\text { витрат на } \\
\text { певний вид } \\
\text { ресурсу }\end{array}$ & $\begin{array}{l}\text { При розрахунку } \\
\text { не задіяні усі } \\
\text { види ресурсів, } \\
\text { ігнорування } \\
\text { перспектив } \\
\text { розвитку } \\
\text { підприємства }\end{array}$ & $\begin{array}{l}3 \text { погляду на те, } \\
\text { що портові } \\
\text { підприємства } \\
\text { фондоємні, } \\
\text { такий підхід } \\
\text { доцільний }\end{array}$ \\
\hline Результативний & \begin{tabular}{|l|} 
Базується на \\
визначенні \\
виробничого \\
потенціалу відпо- \\
відно до суми очіку- \\
ваних доходів, що \\
здатне отримати \\
підприємство від \\
вироб-ничої \\
діяльності
\end{tabular} & $\begin{array}{l}\text { Допомагає } \\
\text { прорахувати } \\
\text { можливі } \\
\text { результати } \\
\text { діяльності та } \\
\text { здійснити } \\
\text { прогноз }\end{array}$ & $\begin{array}{l}\text { Не враховує } \\
\text { окремі складові } \\
\text { ресурсів, } \\
\text { неможливість } \\
\text { досягнення аб- } \\
\text { солютно точних } \\
\text { результатів } \\
\text { через } \\
\text { тривалість } \\
\text { періоду оцінки }\end{array}$ & $\begin{array}{l}\text { В умовах } \\
\text { невизначеності } \\
\text { середовища дуже } \\
\text { складно } \\
\text { використовувати }\end{array}$ \\
\hline $\begin{array}{l}\text { Аналоговий } \\
\text { (порівняльний) }\end{array}$ & $\begin{array}{l}\text { Оцінка будується на } \\
\text { співствленні показ- } \\
\text { ників підприємства } 3 \\
\text { аналогічними показ- } \\
\text { никами конкурентів }\end{array}$ & $\begin{array}{l}\text { Дає змогу } \\
\text { врахувати } \\
\text { ринкову } \\
\text { ситуацію } \\
\text { у цілому }\end{array}$ & $\begin{array}{l}\text { Важко встано- } \\
\text { вити лідера в } \\
\text { галузі, адже } \\
\text { звітність не всіх } \\
\text { підприємств є } \\
\text { відкритою }\end{array}$ & $\begin{array}{l}\text { Як було зазна- } \\
\text { чено раніше, } \\
\text { дуже складно } \\
\text { провести } \\
\text { порівняльний } \\
\text { аналіз між пор- } \\
\text { товими } \\
\text { підприємствами }\end{array}$ \\
\hline
\end{tabular}


Продовження табл. 1

\begin{tabular}{|c|c|c|c|c|}
\hline Назва методу & Зміст методу & Переваги & Недоліки & Доцільність \\
\hline Експертний & $\begin{array}{l}\text { Графоаналітична } \\
\text { методика, що } \\
\text { грунтується на } \\
\text { врахуванні спектра } \\
\text { показників із різних } \\
\text { сфер діяльності та } \\
\text { організаційної } \\
\text { структури за допо- } \\
\text { могою рейтингу } \\
\text { підприємств }\end{array}$ & $\begin{array}{l}\text { Дозволяє оціни- } \\
\text { ти потенціал із } \\
\text { врахуванням } \\
\text { думки експертів, } \\
\text { що безпосеред- } \\
\text { ньо працюють } \\
\text { на підприємстві }\end{array}$ & $\begin{array}{l}\text { Думка } \\
\text { експертів } \\
\text { може бути } \\
\text { суб'єктивною i } \\
\text { не завжди } \\
\text { вірною }\end{array}$ & $\begin{array}{l}\text { Найбільш } \\
\text { поширений } \\
\text { метод на } \\
\text { практиці }\end{array}$ \\
\hline Кореляційний & $\begin{array}{l}\text { Метод із застосу- } \\
\text { ванням кореля- } \\
\text { ційно-регресійних } \\
\text { моделей оціню- } \\
\text { вання виробничого } \\
\text { потенціалу }\end{array}$ & $\begin{array}{l}\text { Дає змогу оці- } \\
\text { нити міру впли- } \\
\text { ву на загальну } \\
\text { величину } \\
\text { результативного } \\
\text { показника } \\
\text { кожного } \\
\text { із факторів }\end{array}$ & $\begin{array}{l}\text { Складність } \\
\text { у побудові } \\
\text { моделі }\end{array}$ & $\begin{array}{l}\text { Інформаційне } \\
\text { поле, що } \\
\text { допомагає } \\
\text { визначити } \\
\text { зв'язок, може } \\
\text { не відповідати } \\
\text { сучасним тен- } \\
\text { денціям }\end{array}$ \\
\hline
\end{tabular}

Джерело: розробка авторів 3 використанням [4; 5; 6]

Таким чином, існує велика кількість підходів та методів оцінювання виробничого потенціалу підприємства, але не всі доцільно використовувати для оцінки виробничого потенціалу портового підприємства, частково тому, що результат базується на статистичній інформації попередніх років, або не враховує особливості цього типу діяльності.

Погоджуючись 3 думкою багатьох авторів, вважаємо, що підхід до оцінювання виробничого потенціалу підприємства, запропонований у роботах П.А. Фоміна і М.К. Старовойтова [6] $\epsilon$ найбільш обгрунтованим, доступним для розуміння, структурованим, а отже таким, що може бути адаптованим для підприємства будь-якої галузі, на підставі оцінювання лише притаманних для цієї галузі показників. А отже цей підхід може використовуватися для проведення оцінювання виробничого потенціалу підприємств.

Підхід, запропонований Фоміним П.А. і Старовойтовим М.К. щодо оцінювання елементів виробничого потенціалу підприємства і формування комплексної оцінки наявного виробничого потенціалу включає декілько етапів.

Етап 1. За обраними елементами пропонується оцінити чотири складових виробничого потенціалу: трудову, техніко-технологічну, інформаційну, сировинну.

Етап 2. Визначення показників за кожною складовою виробничого потенціалу управління, а також технологічних процесів основного і допоміжного виробництв. 
DEVELOPMENT OF MANAGEMENT

AND ENTREPRENEURSHIP METHODS ON TRANSPORT, № 3 (76), 2021
РОЗВИТОК МЕТОДІВ

УПРАВЛІННЯ ТА ГОСПОДАРЮВАННЯ

НА ТРАНСПОРТІ, № 3 (76), 2021
Етап 3. Підготовчий етап методики: визначення рівнів виробничого потенціалу підприємства і їх характеристика; вибір трьох показників по кожній складовій; визначення граничних значень показників (відповідно до рівнів) методом експертних оцінок; визначення значущості кожною складовою виробничого потенціалу підприємства; збір фінансовоекономічної інформації.

Етап 4. Розрахунковий етап методики: розрахунок обраних показників; визначення рівнів показників і відповідних балів; визначення сум балів по складовим і визначення їх рівнів; визначення підсумкового рівня виробничого потенціалу підприємства відповідно до балів, рівнів і значущості показників.

Цей підхід дійсно можливо змінювати в залежності від галузевої особливості підприємства.

За методикою Фоміна П.А. та Старовойтова М.К., на основі системного підходу, оцінки піддається як загальна величина потенціалу підприємства, так і величина його елементів, сумарний потенціал підприємства пропонується розраховувати як інтегральний показник через різнорідність i часом непорівнянність оцінок окремих елементів, а також необхідність урахування синергетичного ефекту їхньої взаємодії [6]. Синергія елементів стратегічного потенціалу підприємства полягає у виникненні додаткового позитивного ефекту від взаємодії усіх елементів у порівнянні з простою сумою їх результатів, що можна пояснити за допомогою формули (1)

$$
\begin{aligned}
\mathrm{C} \Pi \Pi= & \mathrm{C} \Pi \Pi=\sum \int(\mathrm{p} 1 \mathrm{n} \mathrm{i}=1 \mathrm{p} 2, \mathrm{p} 3 \ldots \mathrm{pn}) \\
& \text { умова СПП } \rightarrow \mathrm{pn}+1,
\end{aligned}
$$

де СПП - стратегічний потенціал підприємства;

p1, p2, p3...pn - елементи страте гічного потенціалу підприємства.

Для оцінки виробничого потенціалу на підприємстві загалом варто проаналізувати кожну складову виробничого потенціалу (основні і оборотні фонди, трудові ресурси).

У зв'язку з тим, що ця методика діагностує виробничий потенціал як сумарну оцінку його складових, iii можливо адаптувати для оцінки рівня ефективності використання виробничого потенціалу портового підприємства.

Оцінка кожної складової виробничого потенціалу надає змогу не тільки визначити загальний рівень потенціалу, а також оцінити ефективність використання ресурсів в залежності від значення окремих показників. Інші підходи скоріше визначають загальний рівень потенціалу, не фокусуючи увагу на оцінки повноти його використання.

Перелік показників, що використовують для оцінки кожної складової, може бути різним, наприклад для портового підприємства в оцінці ефективності використання основних фондів критерієм $є$ зростання фондовіддачі, зменшення фондомісткості і як наслідок отримання прибутку.

Але при оцінці використання матеріальних ресурсів основним критерієм не доцільно на наш погляд використовувати зниження матеріаломісткості або збільшення матеріаловіддачі. 
DEVELOPMENT OF MANAGEMENT

AND ENTREPRENEURSHIP METHODS ON TRANSPORT, № 3 (76), 2021
РОЗВИТОК МЕТОДІВ

УПРАВЛІННЯ ТА ГОСПОДАРЮВАННЯ

НА ТРАНСПОРТІ, № 3 (76), 2021

Таблиия 2

Характеристика рівнів виробничого потениіалу портового підприємства

\begin{tabular}{|c|c|c|}
\hline $\begin{array}{c}\text { Рівень } \\
\text { ВПП } \\
\end{array}$ & $\begin{array}{c}\text { Позна- } \\
\text { чення }\end{array}$ & Характеристика \\
\hline 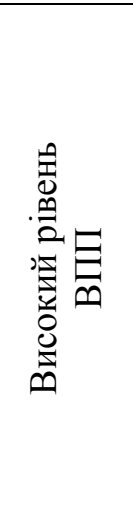 & $\mathrm{A}$ & $\begin{array}{l}\text { Окрім традиційних функцій порти з високим рівнем ВПП } \\
\text { виконують роль центрів міжнародної торгівлі. Тут є офіси } \\
\text { торговельних компаній, розвинені види інфраструктури, } \\
\text { юридичні контори, відділення банків, торговельні зони, } \\
\text { центри зв'язку, у тому числі супутниковою. Це дозволяє } \\
\text { укладати в подібних портах різноманітні угоди, договори } \\
\text { на перевезення і тому подібне. Порти з пасивних обслуго- } \\
\text { вуючих організацій перетворюються на активні транспорт- } \\
\text { ні вузли з широким набором видів послуг: традиційних; } \\
\text { промисловий сервіс портів; адміністративних і комерцій- } \\
\text { них послуг; логістичні послуги в області розподілу ванта- } \\
\text { жів; складський сервіс; інформаційний сервіс. }\end{array}$ \\
\hline 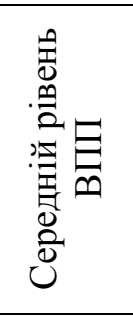 & B & $\begin{array}{l}\text { Порти } 3 \text { середнім рівнем ВПП не лише виконують тради- } \\
\text { ційні функції по перевантаженню вантажів } 3 \text { одного виду } \\
\text { транспорту в іншій, але займаються також промисловим і } \\
\text { торговельним сервісом (упаковка, маркіровка вантажу, } \\
\text { зберігання і первинна переробка). Ці порти (їх називають } \\
\text { «індустріальними») стають не просто транспортними вуз- } \\
\text { лами, але і промисловими і комерційними центрами. }\end{array}$ \\
\hline 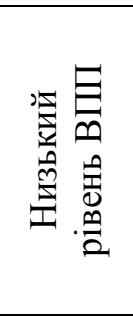 & $\mathrm{C}$ & $\begin{array}{l}\text { Морські порти з низьким рівнем ВПП служать місцем збо- } \\
\text { ру і перевалки вантажів між наземними і морським видами } \\
\text { транспорту. Портова діяльність обмежується НРР, складу- } \\
\text { ванням товарів і навігаційним обслуговуванням морських } \\
\text { суден. Такі умови діяльності портів призводять до їх орга- } \\
\text { нізаційної ізоляції від транспортної і торговельної діяльно- } \\
\text { сті, що значно знижує їх виробничий потенціал. }\end{array}$ \\
\hline
\end{tabular}

Джерело: розробка авторів з використанням [6; 15]

Оцінка кожної складової виробничого потенціалу надає змогу не тільки визначити загальний рівень потенціалу, а також оцінити ефективність використання ресурсів в залежності від значення окремих показників. Інші підходи скоріше визначають загальний рівень потенціалу, не фо- кусуючи увагу на оцінки повноти його використання.

Перелік показників, що використовують для оцінки кожної складової може бути різним, наприклад для портового підприємства в оцінці ефективності використання основних фондів критерієм $\epsilon$ зростання фондо- 
віддачі, зменшення фондомісткості i як наслідок отримання прибутку.

Але при оцінці використання матеріальних ресурсів основним критерієм не доцільно на наш погляд використовувати зниження матеріаломісткості або збільшення матеріаловіддачі.

Для встановлення відповідних критеріїв ми згодні з тим, що доцільно провести кластеризацію досліджуваної за виробничим потенціалом сукупності підприємств та обрати не краще підприємство в галузі, а краще в кластері, до складу якого ввійдуть однорідні за порівнюваними даними (обсягами капіталу, виробленої продукції, технологічними особливостями виробництва) підприємства [12]. Саме застосування методу кластеризації дозволить підвищити обгрунтованість оцінювання ефективності виробничого потенціалу [12].

Організація процедури оцінки виробничого потенціалу можливо розглядати по кожному з основних i допоміжних видів діяльності, де визначаються використані ресурси, які групуються в такий спосіб: фізичні ресурси; при цьому важливими є їх характеристики, наприклад оцінюєть- ся не просто число верстатів, а вік, потужність, ступінь зношеності, циклічність роботи, взаємозамінність i т.д.

Висновки. Таким чином, оцінювання виробничого потенціалу підприємства $\epsilon$ важливим етапом управління, що формує підгрунтя для ідентифікації рівня стану потенціалу та оптимізації управлінських рішень щодо його розвитку. Описана у статті методика розрахунку виробничого потенціалу охоплюює всі основні внутрішньофірмові процеси, що протікають в різних функціональних областях внутрішнього середовища товариства та враховують вплив зовнішнього середовища. У результаті забезпечується системний підхід до управління виробничим потенціалом підприємства, який передбачає виявлення сильних і слабких сторін його діяльності, можливостей та загроз.

Об'єктивна оцінка ефективності використання виробничого потенціалу дає змогу обирати відповідну стратегію розвитку, приймати будь-яке управлінське рішення.

\section{СПИСОК ЛІТЕРАТУРИ}

1. Бай С.І. Розвиток організачії: політика, потенціал, ефективність: монографія. Київ: НТЕУ, 2009. 280 c.

2. Воронкова А.Э. Стратегическое управление конкурентоспособным потенциалом предприятия: диагностика и организация: монографія. Луганск: СНУ им. В Даля, 2004. 314 с.

3. Краснокутська Н.С. Потенціал торговельного підприємства: теорія та методологія дослідження: монографія. Харків: ХДУХТ, 2010. 247 с.

4. Лапин Е.В. Экономический потенщиал предприятия: монография. Сумы: Университетская книга, 2002. 310 c. 
5. Отенко И.П. Методологические основы управления потенциалом предприятия: монография. Харків: ХНЭУ, 2004. 216 с.

6. Перерва П.Г., Побережна Н.М. Визначення ефективності використання виробничого потениіалу машинобудівного підприсмства. Харків: ХНЕУ. URL: https://mmi.fem.sumdu.edu.ua/sites/ default/files/mmi2012_ 2 191 198.pdf

7. Старовойтов М.К., Фомин П.А. Особенности оценки потенциала промышленных предприятий // Антикризисное и внешнее управление: зб. наук. пр. № 2. 2006. С. 27-41.

8. Степанова Т.О. Переваги і недоліки методів управління витратами // Вісник Макіївського економіко-гуманітарного інституту. Макіївка: МЕГІ. 2012. № 12 (25). 119 c.

9. Трофименко Н.А. Оиенка и прогнозирование производственного потенциила предприятия // Вісник СумДУ. Сер. Економіка. 2004. № 9. C. 147-157.

10. Федонін О.С., Репіна I.М., Олексюк О.І. Потениіал підприємства: формування та оцінка: монография. Київ: КНЕУ. 2006. 316 с.

11. Якушева Е.С. Подходы к оченке потенциала предприятия // Проблемь экономики. 2008. №1(20). C. 141-143.

12. Yekimov S.V., Tkachenko V.A., Voit S.N., Zavgorodniy K.V., Zayats O.I. Increasing the Production Potential of an Agricultural Enterprise by Increasing the Motivation of its Employees. URL: https://www. shs-conferences.org/articles/shsconf/abs/2021/04/shsconf_nid2020_04001/ shsconf nid2020 04001.htm

13. Jalilov Bahrom Sotiboldievich. Characteristics Of The Production Potential Of The Enterprise. URL: jpsat.es/index.php/ijpsat/article/view/2548

14. Rakhimov Hasan Shukurjonovich. Assessment of The Economic Efficiency of Development of Transport Infrastructure // International Journal of Research in Management \& Business Studies. Vol. 6, Issue 3 July - Sept. 2019. URL: http://ijrmbs.com/vol6issue3/rakhimov.pdf

15. Luqi Wang, Xiaolong Xue, Zebin Zhao, Zeyu Wang. The Impacts of Transportation Infrastructure on Sustainable Development: Emerging Trends and Challenges, 2018. URL: https://www.ncbi.nlm.nih.gov/pmc/articles/PMC6025045/. DOI: 10.3390/ijerph15061172

\section{REFERENCES}

1. Baj, S.I. (2009). Rozvitok organizatsiyi: politika, potentsial, efektivnist [Development of the organization: policy, potential, efficiency]: monografiya. Kiyv: NTEU, 280 [in Ukrainian].

2. Voronkova, A.E. (2004). Strategicheskoe upravlenie konkurentosposobnyim potentsialom predpriyatiya: diagnostika i organizatsiya [Strategic management of the company's competitive potential: diagnostics and organization]: monograflya. Lugansk: SNU im. V Dalya, 2004, 314 [in Russian]. 
3. Krasnokutska, N.S. (2010). The potential of the trading company: theory and methodology of research [Potentsial torgovelnogo pidpriemstva: teoriya ta metodologiya doslidzhennya]: monografiya. Harkiv: HDUHT, 247 [in Ukrainian].

4. Lapin, E.V. (2002). Ekonomicheskiy potentsial predpriyatiya [Potential of the trade enterprise: theory and method]: monografiya. Sumyi: Universitetskaya kniga, 310 [in Russian].

5. Otenko, I.P. (2004). Metodologicheskie osnovy upravleniya potentsialom predpriyatiya: monografiya. Harkiv: HNEU, 2004, 216 [in Russian].

6. Pererva, P.G. \& Poberezhna, N.M. (2012). Viznachennya efektivnosti vikoristannya virobnichogo potentsialu mashinobudivnogo pidpriemstva [The value of the efficiency of the production potential]. Harkiv: HNEU. Retrieved from: https://mmi.fem.sumdu.edu.ua/sites/default/files/mmi2012_2_191_198.pdf

7. Starovoytov, M.K. \& Fomin, P.A. (2006). Osobennosti otsenki potentsiala promyishlennyih predpriyatiy [Features of the assessment of the potential of industrial enterprises]. Antikrizisnoe $i$ vneshnee upravlenie - Anti-crisis and external management: zb. nauk. pr. № 2, 27-41 [in Russian].

8. Stepanova, T.O. (2012). Perevagi i nedoliki metodiv upravlinnya vitratami [Advantages and disadvantages of cost management methods]. Visnik Makiyivskogo ekonomoko-gumanitarnogo Institutu - Bulletin of the Makeyevka Institute of Economics and Humanities. Makiyivka: MEGI. № 12 (25), 119. [in Ukrainian].

9. Trofimenko, N.A. (2004). Otsenka i prognozirovanie proizvodstvennogo potentsiala predpriyatiya [Assessment and forecasting of the production potential of the enterprise]. Vusnik SumDU. Ser. Ekonommka - Bulletin of SSU. Ser. Economy. № 9, 147-157 [in Russian].

10. Fedonin O.S., Repina I.M. \& Oleksyuk O.I. (2006). Potentsial pidpriemstva: formuvannya ta otsinka [Enterprise potential: formation and evaluation]: monografiya. Kiyv: KNEU. 316 [in Ukrainian].

11. Yakusheva E.S. (2008). Podhodyi $k$ otsenke potentsiala predpriyatiya [Approaches to assessing the potential of the enterprise]. Problemyi ekonomikiProblems of the economy. № 1(20), 141-143. [in Russian].

12. Yekimov S.V., Tkachenko V.A., Voit S.N., Zavgorodniy K.V., Zayats O.I. Increasing the Production Potential of an Agricultural Enterprise by Increasing the Motivation of its Employees. Retrieved from: https://www. shs-conferences.org/articles/shsconf/abs/2021/04/ shsconf_nid2020_04001/ shsconf_nid2020_04001.htm

13. Jalilov Bahrom Sotiboldievich. Characteristics Of The Production Potential Of The Enterprise. Retrieved from: jpsat.es/index.php/ijpsat/article/view/2548

14. Rakhimov Hasan Shukurjonovich (2019). Assessment of The Economic Efficiency of Development of Transport Infrastructure. International Journal of 
Research in Management \& Business Studies. Vol. 6, Issue 3. Retrieved from: http://ijrmbs.com/vol6issue3/rakhimov.pdf

15. Luqi Wang, Xiaolong Xue, Zebin Zhao \& Zeyu Wang (2018). The Impacts of Transportation Infrastructure on Sustainable Development: Emerging Trends and Challenges. Retrieved from: https://www.ncbi.nlm.nih.gov/pmc/articles/ PMC6025045/. DOI: 10.3390/ijerph15061172

Стаття надійшла 02.09.2021

Посилання на статтю: Чиж Л.П., Хотсєва Н.В., Загородня К.О. Методика оцінки рівня ефективності використання виробничого потенціалу підприємства портової діяльності // Розвиток методів управління та господарювання на транспорті: Зб. наук. праць, 2021. № 3 (76). C. 5-16. DOI 10.31375/2226-1915-2021-3-5-16.

Article received 24.09.2021

Reference a JournalArtic: Chiz, Lyudmila, Khoteeva, Natalia \& Zagorodnya, Karina. (2021). Methods of evaluation of efficiency of use of production potential of port enterprise. Development of management and entrepreneurship methods on transport. 3 (76), 5-16. DOI 10.31375/2226-1915-2021-3-5-16. 